\title{
Unable to Perform
}

National Cancer Institute

\section{Source}

National Cancer Institute. Unable to Perform. NCI Thesaurus. Code C131120.

An indication that an action, task, or function was not done due to a lack of skill, means, or opportunity. 